\title{
Review
}

\section{The Role of lncRNAs in Gene Expression Regulation through mRNA Stabilization}

\author{
Maialen Sebastian-delaCruz ${ }^{1,2} \mathbb{D}^{\mathbb{D}}$, Itziar Gonzalez-Moro ${ }^{2,3} \mathbb{D}^{\mathrm{D}}$, Ane Olazagoitia-Garmendia ${ }^{1,2}$, \\ Ainara Castellanos-Rubio ${ }^{1,2,4,5}$ (D) and Izortze Santin $2,3,5, *$ (D)
}

Citation: Sebastian-delaCruz, M.; Gonzalez-Moro, I.;

Olazagoitia-Garmendia, A.;

Castellanos-Rubio, A.; Santin, I. The

Role of lncRNAs in Gene

Expression Regulation

through mRNA Stabilization.

Non-coding RNA 2021, 7, 3.

http://doi.org/10.3390/ncrna 7010003

Received: 9 December 2020

Accepted: 30 December 2020

Published: 5 January 2021

Publisher's Note: MDPI stays neutral with regard to jurisdictional clai$\mathrm{ms}$ in published maps and institutional affiliations.

Copyright: () 2021 by the authors. Licensee MDPI, Basel, Switzerland. This article is an open access article distributed under the terms and conditions of the Creative Commons Attribution (CC BY) license (https:// creativecommons.org/licenses/by/ $4.0 /)$.
1 Department of Genetics, Physical Anthropology and Animal Physiology, University of the Basque Country, 48940 Leioa, Spain; maialen.sebastian@ehu.eus (M.S.-d.); ane.olazagoitia@ehu.eus (A.O.-G.); ainara.castellanos@ehu.eus (A.C.-R.)

2 Biocruces Bizkaia Health Research Institute, 48903 Barakaldo, Spain; itziar.gonzalezm@ehu.eus

3 Department of Biochemistry and Molecular Biology, University of the Basque Country, 48940 Leioa, Spain

4 Ikerbasque, Basque Foundation for Science, 48009 Bilbao, Spain

5 CIBER de Diabetes y Enfermedades Metabólicas Asociadas (CIBERDEM), Instituto de Salud Carlos III, 28029 Madrid, Spain

* Correspondence: izortze.santin@ehu.eus; Tel.: +34-94-601-32-09

\begin{abstract}
RNA stability influences gene expression and translation in almost all living organisms, and the levels of mRNA molecules in the cell are determined by a balance between production and decay. Maintaining an accurate balance is crucial for the correct function of a wide variety of biological processes and to maintain an appropriate cellular homeostasis. Long non-coding RNAs (lncRNAs) have been shown to participate in the regulation of gene expression through different molecular mechanisms, including mRNA stabilization. In this review we provide an overview on the molecular mechanisms by which lncRNAs modulate mRNA stability and decay. We focus on how lncRNAs interact with RNA binding proteins and microRNAs to avoid mRNA degradation, and also on how lncRNAs modulate epitranscriptomic marks that directly impact on mRNA stability.
\end{abstract}

Keywords: long non-coding RNA; mRNA stability; RNA binding protein; microRNA; gene expression

\section{Introduction}

Gene expression and translation is influenced by messenger RNA (mRNA) stability in almost all living organisms. mRNA from bacterial cells can last from seconds to more than one hour, but on average it stays functional between 1 and $3 \mathrm{~min}[1,2]$. Conversely, the lifetime of mammalian mRNA ranges from a couple of minutes to even days, making eukaryotic mRNA more stable than bacterial mRNA. However, from bacteria to mammals, mRNA lifetime needs to be finely regulated in order to enable correct cell homeostasis [1]. The control of the abundance of a particular mRNA fluctuates to adapt to environmental changes, cell growth, differentiation, or to adjust to an unfamiliar situation [3,4]. In this line, the regulation of mRNA stability is essential for tissues and organs exposed to stress signals, such as starvation, infection, inflammation, toxins, or tissue invasion by immune cells $[5,6]$.

The levels of mRNA molecules in the cell are determined by a balance between production and decay $[7,8]$. Maintaining an accurate balance is crucial for the correct function of a wide variety of biological processes and for the maintenance of an appropriate cellular homeostasis. Many variables such as primary and secondary structure, translation rate and location, among others, influence mRNA stability $[5,9,10]$, and thus minor changes in the structure or the sequence of mRNA molecules might directly influence their half-life.

Eukaryotic mRNAs are transcribed in the nucleus, they are capped (7-methylguanosine cap in $5^{\prime}$ end), spliced, polyadenylated (poly(A) tail in $3^{\prime}$ end), and lastly, mature mRNAs 
are exported to the cytoplasm where they are translated into the corresponding polypeptides [1]. Once in the cytoplasm, the $5^{\prime}$ cap and the $3^{\prime}$ tail serve to attract specific protein complexes that regulate mRNA stability, via protecting mRNA molecules from the attack of ribonucleases and decapping enzymes [1,9,11].

In the last few years, significant progress has been made towards the understanding of mRNA degradation and stability. In general, the decay of mRNA molecules in eukaryotic cells starts with the deadenylation and/or decapping of the mature mRNA, followed by degradation carried out by exonucleases [12-15]. However, the regulation of mRNA stability depends largely on how a three step process (deadenylation, decapping, and degradation) is modulated by regulatory factors, and thus these factors should be taken into account when analyzing the regulation of mRNA stability. Indeed, several studies have pointed out the key role of RNA-binding proteins and miRNAs in the regulation of this process $[7,9,16,17]$. In addition, long non-coding RNAs (lncRNAs) are emerging as prominent regulators of mRNA stability and decay [3,4,18-21]. LncRNAs are RNA molecules without protein coding potential with lengths exceeding 200 nucleotides [22]. They play important roles in biological processes such as chromatin remodeling, transcriptional activation and interference, RNA processing, and mRNA translation [23]. Regarding their mechanisms of action, different models have been proposed, including functioning as signal, decoy, scaffold, guide, and enhancer RNAs [24]. Importantly, the expression of IncRNAs occurs in a cell-, tissue-, and species-specific manner, and accumulating evidence suggests that different splice variants of individual lncRNAs are also expressed in a cell-, tissue-, and species-specific way [25].

In this review we provide an overview of the main molecular mechanisms by which lncRNAs modulate mRNA stability and gene expression (Figure 1). A detailed description of how lncRNAs interact with target mRNAs, RNA binding proteins or miRNAs to avoid mRNA degradation is provided and a brief explanation on how lncRNAs modulate epitranscriptomic changes to impact on mRNA stability is also described.

A

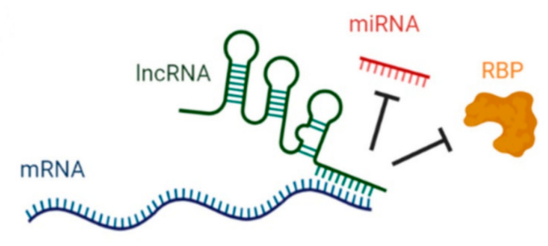

B
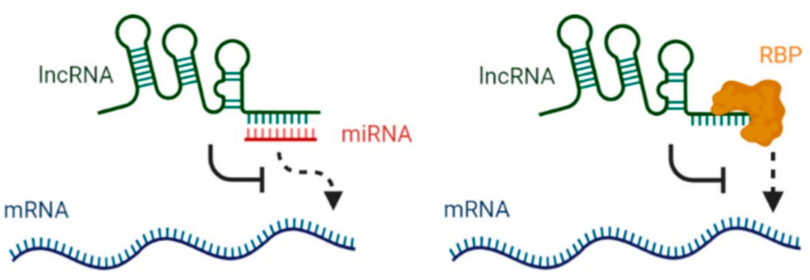

C
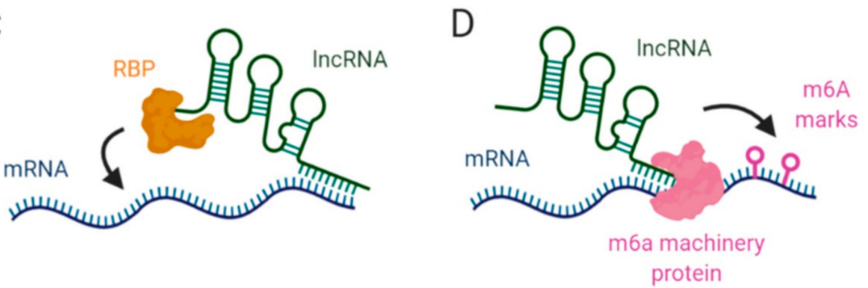

Figure 1. Mechanisms of action of lncRNA-mediated mRNA stability regulation. LncRNAs can modulate mRNA stability through different mechanisms: (A) Direct interaction with miRNA or RBP binding sites in target mRNA; (B) Sequestration of miRNAs or RBPs to avoid their interaction with mRNA molecules; (C) Acting as scaffolds to enhance RBP-mRNA interactions; (D) Interaction with m6A machinery to modulate m6A levels of target mRNAs. 


\section{LncRNAs Affecting mRNA Stability via miRNA Blockage}

Recent several studies have been focused on the analysis of the cross-talk between non-coding and coding RNAs to characterize the implication of these interactions in several processes that include chromatin remodeling, mRNA and protein stability, transcription, and mRNA turnover [26]. Accumulating evidence has demonstrated that microRNAs (miRNAs), which are non-coding RNA molecules of around 22 nucleotides, and long non-coding RNAs, which are longer than 200 nucleotides, interact to regulate their own expression and the expression of mRNAs through several molecular mechanisms [27-30]. MicroRNAs can silence cytoplasmic mRNAs by triggering an endonuclease cleavage, by promoting translation repression or by accelerating mRNA deadenylation and decapping [31,32]. Thus, miRNA blocking by lncRNAs can directly inhibit these processes, promoting mRNA stabilization and inducing gene expression.

In this section, we will provide an overview of lncRNAs that prevent interaction of miRNAs with target mRNAs to protect them from miRNA-driven degradation. These lncRNAs are referred to as competitive endogenous RNAs (ceRNAs), decoys or sponges [33]. LncRNAs can act as ceRNAs by two different mechanisms. On the one hand, they are able to sequester miRNAs, avoiding their binding to target mRNAs, and on the other hand, they can directly interact with target mRNA transcripts to block miRNA binding sites in mRNA molecules. In this case, lncRNAs and miRNAs share common binding sites in the target mRNA. The interactions between miRNAs and ceRNAs are crucial for the regulation of several basal biological processes but have also been described to participate in different pathogenic conditions.

Most lncRNAs that block miRNA activity to enhance mRNA stability are transcribed from the opposite DNA strand to their paired (sometimes complementary) sense protein coding genes and are known as natural antisense transcripts (NATs). Even though there are some examples of NATs that code for proteins, such as Wrap53 [34] and DHPS [35], NATs usually lack protein coding potential [36] and are generally classified as lncRNAs [37]. NATs can alter their paired sense gene expression by exerting their effect at different levels, including transcription, mRNA processing, splicing, stability and translation [36,38-41]. Regarding the mechanisms by which NATs alter mRNA stability, the "Recycling hypothesis" suggests that reversible RNA duplex formation might trigger conformational changes in mRNA molecules, hindering the accessibility to RNA binding proteins (RBPs), both stabilizing and destabilizing RBPs, and miRNAs [37].

The best characterized NAT is probably the lncRNA BACE1 antisense RNA (BACE1$A S)$. This lncRNA is partially antisense to $B A C E 1$, a gene encoding the $\beta$-site amyloid precursor protein cleaving enzyme 1, which plays a crucial role in the pathophysiology of Alzheimer's disease [42]. Interestingly, it has been shown that lncRNA BACE1-AS is markedly up-regulated in brain samples from patients with Alzheimer's disease and promotes the stability of the BACE1 transcript [43]. The lncRNA BACE1-AS regulates the expression of its sense partner through a synergistic mechanism that includes prevention of miRNA-induced mRNA decay and translational repression. Specifically, miR-485-5p and $B A C E 1-A S$ share a common binding site in the sixth exon of BACE1 mRNA transcript, and thus binding of $B A C E 1-A S$ to this site avoids the interaction of $m i R-485-5 p$, hindering the translational repression and destabilization of BACE1 mRNA by miR-485-5p, and eventually elevating $B A C E 1$ levels [43].

Similar to BACE1-AS, PTB antisense RNA (PTB-AS) also modulates its sense mRNA stability by masking miRNA binding sites [44]. PTB-AS binds to the $3^{\prime}$ untranslated region (UTR) of PTBP1, a RBP that promotes gliomagenesis [45], and prevents miR-9 binding, a neural-specific miRNA known to target the $3^{\prime}$ UTR of PTBP1 for degradation [46].

In addition, a lncRNA named FGFR3 antisense transcript 1 (FGFR3-AS1) which is antisense to FGFR3 gene, was shown to be upregulated in an expression analysis performed in tumorigenic tissue from patients with osteosarcoma, when compared to non-cancerous tissue [30]. Bioinformatic analysis indicated that FGFR3-AS1 and FGFR3 formed a "tailto-tail" fully complementarity pairing pattern composed of 1053 nucleotides, suggesting 
a potential regulatory effect of FGFR3-AS1 in the expression of the FGFR3 gene. In silico results were confirmed by RNA protection assays that showed that the non-overlapping part of FGFR3 mRNA was totally digested, but the overlapping $3^{\prime} U T R$ of FGFR3 mRNA was protected from RNase digestion. Moreover, the authors showed that this antisense pairing between FGFR3-AS1 and FGFR3 mRNA upregulated FGFR3 expression by increasing FGFR3 mRNA stability. Interestingly, many miRNAs have been reported to bind to the 3'UTR of FGFR3, inducing FGFR3 mRNA degradation [47]. Thus, the antisense pairing between FGFR3-AS1 and the $3^{\prime} \mathrm{UTR}$ of FGFR3 might block potential miRNA binding sites, protecting FGFR 3 from miRNA-induced degradation and/or translation inhibition. However, whether FGFR3-AS1-driven FGFR3 mRNA stabilization occurs through this mechanism remains to be clarified.

Paxillin antisense RNA 1 (PXN-AS1), a lncRNA overlapping PXN mRNA, was identified after discovering alternative splicing events on a transcriptome sequencing analysis of a hepatocellular carcinoma (HCC) cell line with stable deletion of Muscleblind-like-3 (MBNL3), an oncofetal splicing factor. Two main transcripts were identified: lncRNA PXN-AS1-L (containing exon 4) and lncRNA PXN-AS1-S (lacking exon 4). Both, PXN$A S 1-L$ and $P X N-A S 1-S$, were preferentially expressed in the cytoplasm, but had different regulatory effects on the expression of the PXN transcript. While PXN-AS1-L upregulated PXN protein, $P X N-A S 1-S$ downregulated it. Interestingly, $P X N-A S 1-L$ upregulated $P X N$ mRNA by preventing miRNA-24-AGO2 complex binding to the $3^{\prime}$ UTR of PXN mRNA [48].

The lncRNA Sirt1 antisense (Sirt1-AS) is transcribed from the Sirt1 antisense strand and has been shown to interact with Sirt1 mRNA, forming an RNA duplex that increases stability of its paired transcript, prolonging its half-life up to $10 \mathrm{~h}$ and eventually augmenting SIRT1 protein expression [49]. Using luciferase assay experiments it was shown that Sirt1-AS lncRNA interacted with the $3^{\prime}$ UTR of the Sirt1 mRNA transcript. This interaction masked miR-3a binding sites, avoiding miR-3a-driven Sirt1 mRNA degradation. Interestingly, SIRT1 is a NAD-dependent class III protein deacetylase, which regulates the balance between myoblast proliferation and differentiation, and plays a crucial role in muscle formation [50]. Thus, lncRNA Sirt1-AS might participate in myogenesis by blocking miR-34a binding to Sirt1 mRNA which turns in increased SIRT1 protein and increased myoblast proliferation.

Similar to Sirt1-AS, a lncRNA named Urothelial Cancer Associated 1 (UCA1) has been shown to regulate mRNA stabilization through directly binding to $3^{\prime}$ UTRs of target mRNAs to protect them from miRNA-mediated degradation [51].

Other mechanisms by which lncRNAs block the effect of miRNAs on mRNA degradation are the ones described in the "Competing endogenous RNA" hypothesis, in which lncRNAs compete with miRNAs or RBPs to bind the same common target sequence in mRNAs. Some examples of lncRNAs that act as ceRNAs are described in the following paragraphs.

In addition to the ability to prevent miRNA-induced degradation by binding to mRNA transcripts, it has been described that UCA1 can also control mRNA stabilization and gene expression by sponging miRNAs that negatively regulate gene expression [51]. In this specific case, lncRNA UCA1 was implicated in the progression of colorectal cancer through its capacity to control a ceRNA network that fostered upregulation of several genes, including ANLN, BIRC5, IPO7, KIF2A, and KIF23.

OIP5 Antisense RNA 1 (OIP5-AS1) is the mammalian homolog of Cyrano gene in zebrafish and it is important for controlling neurogenesis during development [52]. It is located upstream of the OIP5 sense gene, but they do not overlap. It is known to act as a ceRNA for $m i R-143-3 p$ in cervical cancer (CC) cells, sustaining the expression of miR143-3p-targets, ITGA6 [53] and SMAD3 [54], and promoting proliferation, migration and invasion of CC cells $[53,54]$.

Another lncRNA acting as a ceRNA that affects mRNA stability is MACC1 Antisense RNA 1 (MACC1-AS1), an intronic antisense lncRNA located between the fourth and fifth exon of $M A C C 1$, a transcriptional regulator of epithelial-mesenchymal transition (EMT) [55] 
that enhances gastric tumor progression [56]. It shares binding sites for $m i R-384$ and $m i R-$ 145-3p within PTN and c-Myc transcripts respectively, which are two well-known oncogenic genes [57]. Similar to lncRNA OIP5-AS1, MACC1-AS1 has the capacity to sequester miR-384 and $m i R-145-3 p$, sustaining the stability of PTN and $c-M y c$ mRNAs, and promoting cell proliferation and tumorigenesis.

Other lncRNA that also acts as a miRNA sponge is lncRNA PTENP1pg1 [58]. PTENpg1 controls the expression of the tumor suppressor gene PTEN, and thus, plays a crucial role in tumorigenesis processes. Interestingly, antisense to this PTENP1pg1, there is another lncRNA named PTENP1pg1-AS, which has two isoforms, alpha and beta. While the alpha isoform functions in trans and epigenetically modulates PTEN transcription by the recruitment of DNMT3a and EZH2, the beta isoform interacts with PTENpg1 through an RNA:RNA pairing interaction, affecting PTEN protein output via changes of PTENpg1 stability and microRNA sponge activity.

It is also worth mentioning the lncRNA uc.173 that inhibits miRNA function through a molecular mechanism that implies posttranscriptional reduction of a pri-miRNA. This lncRNA is transcribed from an ultraconserved region (UCR) in human chromosome 3. UCRs represent conserved sequences of the human genome that are likely to be functional but do not have coding potential [59]. RNA molecules transcribed from UCRs originate from genomic regions located in both intra- and intergenic regions with almost perfect evolutionary conservation in most of the mammalian genomes, suggesting that may have a key function in cell physiology and pathogenic processes [59]. Indeed, lncRNA uc.173 has been described to be implicated in intestinal mucosal cell growth and renewal [60]. This lncRNA, which is highly expressed in intestinal mucosa, stimulates intestinal epithelial cell renewal by downregulating miRNA195 expression through posttranscriptional reduction of pri-miR-195. Although the precise molecular mechanisms by which this lncRNA destabilizes the pri-miR-195 transcript are unknown, it seems that the process is achieved through a direct lncRNA-mRNA interaction that enhances the degradation of pri-miR-195 transcript. Downregulation of miRNA195 by lncRNA uc.173 results in upregulation of genes implicated in intestinal epithelium growth [60].

Finally, another interesting example is the tumor-promoting lncRNA ncNRFR (noncoding Nras functional RNA). This lncRNA contains a 22-nucleotide sequence that is identical to miRNA let-7a and differs from other miRNAs (let-7b, let-7c, let-7d, let-7e, let-7f, let-7g, let-7i, and miR-98) in only 1-4 nucleotides [61]. Overexpression of $n c N R F R$ in a cell line of colon epithelial cells increased the activity of a heterologous reporter bearing a miRNA let-7 target site, suggesting that ncNRFR lowered miRNA let-7 function. The miRNA let-7 is a tumor suppressor that inhibits the expression of several oncogenes, and thus tumorigenic function of $n c N R F R$ might be linked to its ability to suppress the action of miRNA let-7 upon endogenous target mRNAs. The molecular mechanisms by which ncNRFR blocks let-7 remain to be clarified, although taking into account the high homology in the sequence of these two ncRNAs, it is plausible to think that ncNRFR might directly compete with let-7 to bind target mRNA transcripts and inhibit let-7-mediated mRNA degradation.

In summary, during the last few years it has become apparent that there is a significant crosstalk between miRNAs and lncRNAs in the regulation of gene expression. Indeed, various ceRNAs have already been identified and their capacity either to sequester miRNAs or to block miRNA binding to target mRNAs has been widely described. Sequestration or blocking of miRNAs by lncRNAs implies a reduced interaction of the miRNAs with their target mRNAs, which eventually turns into increased mRNA stability and expression. Although this field of research has just started to emerge, future studies analyzing the interaction between these two non-coding molecules will explain many of the "unknowns" that still linger regarding the regulation of gene expression, both in basal and pathogenic conditions. 


\section{Interaction between lncRNAs and RBPs in mRNA Stabilization}

It is well established that AU-rich elements (AREs) [62] and GU-rich elements (GREs) [63] are distinct sequence elements in the 3'-UTR of mRNAs. These regions are among the most common determinants of RNA stability in mammalian cells by which various RNA binding proteins (RBPs), including both stabilizing and destabilizing factors bind to, thereby modulating mRNA stability and/or translational efficiency [64]. There exist hundreds of different RBPs with a diverse number of functions through distinct RNA binding domains to which proteins bind and affect RNA fate [65].

A wide variety of research works have shown how RBPs directly bind to mRNA to accelerate mRNA decay or affect translation (increasing or blocking the processes) [64,66]. Interestingly, more and more lncRNAs are being described to also bind RBPs [67-69]. One of the best studied lncRNAs, Xist, can form ribonucleoprotein complexes (RNPs) in the nucleus to affect target gene transcription regulation [70]. It has been shown that lncRNAs can also be cytoplasmic and bind RBPs to affect other mRNA metabolism processes such as mRNA stability and turnover [71-73]. Depending on which factors interact with a given lncRNA, this could increase or decrease the targeted mRNA.

In some cases, lncRNAs bind to mRNA transcripts and help to recruit RBPs (stabilizing or destabilizing) affecting mRNA levels. For example, the LncRNA-assisted stabilization of transcripts (LAST) can stabilize CCND1 mRNA through protection against nuclease activity by promoting the interaction between the RBP named CNBP and the $5^{\prime} \mathrm{UTR}$ of CCND1 mRNA [74]. In other cases, lncRNAs prevent RBP and target mRNAs interaction by binding the mRNA transcript. This is the case of the lncRNA Sros1, which blocks the binding of Stat1 mRNA to the RBP CAPRIN1, stabilizing the Stat1 mRNA [75], and of lncRNA 7SL, which interacts with the 3'UTR of TP53 mRNA, thereby preventing HuR binding and repressing TP53 translation [76].

Another example is PDCD4 Antisense RNA 1 (PDCD4-AS1), a NAT affecting stability of PDCD4, which is a tumor suppressor coding gene implicated in breast cancer (BC) [77]. In a study by Jadaliha et al. [78], overlapping regions between PDCD4-AS1 and PDCD4 were reported. Thus, PDCD4-AS1 and PDCD4 mRNA were found to form an RNA duplex, inducing an increase in PDCD4 mRNA stability. In this case, RNA duplex formation prevented the interaction between PDCD4 mRNA and HuR [79]. Although HuR usually acts as a stabilizing protein, it has been shown that HuR can form a complex with KSRP to destabilize mRNA molecules and induce a significant reduction in specific protein levels [79].

It is also possible that lncRNA-RBPs interactions influence downstream target mRNA. In turn, LINC00324 [80], TRPM2 Antisense RNA (TRPM2-AS) [81], lncRNA MY [82], lncRNA MEG3 [83], lncRNA Gadd7 [84], lncRNA FIRRE [85], or lncRNA H19 [86] among others, can bind different RBPs (both stabilizing and destabilizing), and thus affect target mRNA decay.

There are also lncRNA-RBP interactions that would indirectly affect mRNA. There are some lncRNAs that modulate RBP activity and hence, will affect downstream mRNA levels. LncRNA NORAD has been described to sequester PUMILIO proteins, which are key regulators for many mRNA stability and translation processes. Thus, NORAD-PUMILIO interaction represses mRNA stability and translation of target mRNAs [87]. LncRNAs OCC1 and OIP5-AS1 have also been described to bind HuR (a RBP that binds to thousands of mRNAs). While OCC1 enhances HuR degradation [88], OIP5-AS1 functions as a sponge for $\mathrm{HuR}$ and prevents binding to its targets [89]. In the case of treRNA1, this lncRNA downregulates the expression of E-cadherin by suppressing the translation of its mRNA. TreRNA1 forms an RNP complex that, in turn, binds to eIF4G1 (an initiation factor of protein synthesis) affecting translation of the target mRNA [90].

It is also known that RBPs can influence lncRNA stability, that could also affect lncRNA function and target mRNAs at different levels. LincRNA-p21 interacts with target CTNNB1 and JUNB mRNAs and inhibits their translation efficiency. However, HuR RBP can inhibit the expression of lincRNA-p21 by inducing its degradation, which promotes the binding of HuR to CTNNB1 and JUNB mRNAs enhancing their translation, thus increasing the 
levels of these proteins [91]. The cytoplasmic RBP HuD can also increase the stability of $B A C E 1-A S$ to further influence target mRNA stability [92].

However, IncRNAs can also reduce mRNA stability, making transcripts prone to degradation. One mechanism by which this happens is the Staufen 1 mediated decay. Staufen 1 (STAU1) protein binds the 3'UTR that contain duplex RNA structures to mediate mRNA decay and regulate gene expression [93]. LncRNAs have been found to form STAU1 binding sites by interacting with the $3^{\prime} \mathrm{UTR}$ of coding genes, thus downregulating their expression [94]. TINCR IncRNA was first found to bind STAU1 protein in the context of epidermal differentiation [95]. Further studies performed in gastric cancer, confirmed the binding of TINCR to STAU1 protein and found that this interaction induced the STAU1 mediated decay of KLF2 mRNA. KLF2, which induces apoptosis, was described to be reduced in the cancer tissues, opposite to what happens to TINCR. Thus, interaction of TINCR lncRNA with STAU1 in cancer cells induces the degradation of KLF2, preventing apoptosis and contributing to the oncogenic potential of gastric carcinoma [96]. Additionally, other mechanisms of lncRNA-mediated mRNA degradation have also been described. As it is the case of $a H I F$ antisense lncRNA, which overlaps the $3^{\prime}$ UTR of HIF1a coding gene, and has the ability to destabilize HIF1a mRNA, subsequently decreasing HIF- $1 \alpha$ protein expression in response to chronic hypoxia [97]. Rossignol F. et al. hypothesized that this destabilization occurs via $a H I F-$ mediated exposure of AU rich elements present in the $3^{\prime}$ UTR of HIF1a mRNA, although the molecular mechanisms by which the mRNA is degraded have not been described yet [98].

All these RNA-protein complexes rely mostly in RNA secondary and tertiary structures that allow the direct interaction between molecules. Therefore, impairment of RNA structure will affect binding and function of the complex, leading to dysregulation of the related pathways $[65,99]$. There is growing evidence about disease-associated SNPs affecting lncRNA structure $[100,101]$. Taking into account that many complex disease-associated SNPs are enriched within lncRNAs [102], identifying those lncRNAs and how their binding to RBPs is affected could help find key targets in the associated diseases. One example is Inc13, which regulates the stability of STAT1 mRNA in pancreatic beta cells [103]. Lnc13 was first discovered in the context of celiac disease, a chronic inflammatory disorder of the intestine, where it has a stability-unrelated function and it regulates gene expression in the chromatin [104]. However, Gonzalez-Moro I. et al. recently related $\operatorname{lnc} 13$ with other autoimmune disorder, type 1 diabetes (T1D), as they found that upregulation of $\operatorname{lnc} 13$ in pancreatic beta cells induces the activation of the pro-inflammatory STAT1 pathway promoting the production of downstream inflammatory chemokines. Lnc13 was found to enhance STAT1 protein levels by stabilizing its mRNA via interaction with the protein PCBP2 (Poly (rC)-binding protein 2) in the cytoplasm. Viral infections, which have been proposed as triggering factors for T1D [105], were found to induce $\operatorname{lnc} 13$ translocation from the nucleus to the cytoplasm, enabling the interaction of STAT1 mRNA with PCBP2, which promotes the signaling events that will ultimately lead to pancreatic beta cell destruction and T1D development [103].

Finally, the cell specific expression and functions of lncRNAs should be taken into consideration as this broadens the pathways that can be affected by IncRNA function. For example, Linc-RoR interacts with both hnRNP I (stabilizing factor) and AUF1 (destabilizing factor), with an opposite consequence in their interaction with $c-M y c$ mRNA [106]. Alternatively, lncRNA Epr changes Cdkn1a gene expression by affecting both its transcription and mRNA decay through its association with the transcription factor SMAD3 or the RBP KHSRP, respectively. KHSRP is predominantly an mRNA decay promoting factor in epithelial cells and the interaction with Epr blocks its ability to induce decay of Cdkn1a mRNA $[107,108]$.

All these mechanisms show the importance of studying lncRNA regulatory roles in mRNA stability and turnover, but also demonstrate the intricate work beyond studies for lncRNA functional characterization. 


\section{LncRNAs, Epitranscriptomic Changes and mRNA Stability}

RNA modifications have been recently involved in the regulation of mRNA stability and it has been stated that the regulation of mRNA stability through RNA modification is a crucial step for the tight regulation of gene expression [109]. N6-methyladenosine $\left(\mathrm{m}^{6} \mathrm{~A}\right)$ methylation is the most prevalent RNA modification in mRNAs and noncoding RNAs, and it has been involved in a wide range of RNA metabolic processes, including stability [110].

YTHDF2, an $\mathrm{m}^{6} \mathrm{~A}$ reader protein, has been described to selectively bind to $\mathrm{m}^{6} \mathrm{~A}$ containing mRNAs, resulting in the localization of bound mRNAs from the translatable pool to cellular mRNA decay sites, such as processing bodies [110]. In contrast to the mRNA-decay-promoting function of YTHDF2, insulin-like growth factor 2 mRNAbinding proteins (IGF2BPs) promote the stability and storage of target mRNAs in an $\mathrm{m}^{6} \mathrm{~A}$-dependent manner [111]. The opposite role of IGF2BPs versus YTHDF2 imposes an additional layer of complexity on $\mathrm{m}^{6} \mathrm{~A}$ function. IGF2BPs and YTHDF2 may recognize different targets or compete for the same $\mathrm{m}^{6} \mathrm{~A}$ sites to fine-tune expression of shared targets through controlling the balance between mRNA stabilization and decay [111]. On the other hand, another $\mathrm{m}^{6} \mathrm{~A}$ reader protein, YTHDF1, actively promotes protein synthesis by interacting with the translation machinery [112]. Altogether, YTHDF2 and IGF2BPs control the lifetime of target transcripts, whereas YTHDF1-mediated translation promotion increases translation efficiency.

In this context, there are few works describing lncRNAs influencing $\mathrm{m}^{6} \mathrm{~A}$-mediated mRNA stability. GAS5-AS1 interacts with the tumor suppressor GAS5 and increases its stability by influencing the interaction between GAS5 mRNA and the RNA demethylase ALKBH5 leading to a decreased GAS5 $\mathrm{m}^{6} \mathrm{~A}$ methylation. Moreover, it was shown that $\mathrm{m}^{6} \mathrm{~A}$-mediated GAS5 mRNA degradation relies on YTHDF2-dependent pathway [113]. LINC00470 associates with PTEN mRNA and suppresses its stability through interaction with the $\mathrm{m}^{6} \mathrm{~A}$ writer METTL3. In addition, LINC00470-METTL3-mediated PTEN mRNA degradation also relies on YTHDF2 [114]. Lastly, LIN28B-AS1 is able to regulate mRNA stability of LIN28B by directly interacting with IGF2BP1 but not with LIN28B, as IGF2BP1 affects LIN28B mRNA stabilization [115].

In the context of mRNA-lncRNA interactions, lncRNA LNC942, upregulated in breast cancer, has been described to interact with the methylase METTL4 driving it to the mRNA of target genes CXCR4 and CYP1B1. These two genes are involved in breast cancer initiation and progression, and their methylation augments the stability of the mRNA molecules, which results on higher protein levels and induction of tumorigenesis [115] probably due to an increased interaction with IGF2BP and YTHDF1 readers.

\section{Concluding Remarks and Future Prospects}

Correct tuning of mRNA stability is a crucial process to maintain appropriate homeostasis, and thus its dysregulation may lead to the development of several pathologies, including cancer. Stability of mRNA molecules is tightly regulated by several mechanisms, including the action of lncRNA molecules. During the last few years, lncRNAs have been implicated in the modulation of mRNA stability and several mechanisms of action have been described. On the one hand, they can prevent miRNA- and RBP-binding to target mRNAs by blocking target binding sites through direct lncRNA-mRNA interaction. On the other hand, they can sequester miRNAs and RBPs to avoid their interaction with target mRNAs, or to inhibit RBP-driven posttranscriptional modifications that affect mRNA stability. Thus, lncRNAs have emerged as crucial regulators of mRNA stability, another molecular mechanism by which these non-coding molecules participate in the regulation of gene expression.

Taking into account that lncRNAs play important roles in the regulation of mRNA stability, the functional characterization of the molecular mechanisms by which these noncoding molecules participate on mRNA equilibrium maintenance will open the door to the development of new lncRNA-based strategies to modify mRNA half-life and subsequent protein expression. Additionally, the functional understanding of lncRNAs that regulate 
mRNA stability in non-mammalian organisms as Drosophila melanogaster or zebrafish, which are easier to genetically manipulate, will help find human orthologous lncRNAs important in mRNA biology. As described formerly in this review, lncRNA-driven mRNA stability changes might impact several biological processes which are important, in both, health and disease. Thus, a better understanding of how lncRNAs act on mRNA stability will provide useful information for the development of new therapeutic strategies to treat and / or cure several diseases in which a dysregulated gene expression pattern is responsible of their development.

Author Contributions: M.S.-d., I.G.-M., A.O.-G., A.C.-R. and I.S. performed the bibliographic research, wrote, revised, and approved the final version of the manuscript. I.S. is the guarantor of this work. All authors have read and agreed to the published version of the manuscript.

Funding: LncRNA work in author's laboratory is supported by European Foundation for the Study of Diabetes (EFSD)-EFSD/JDRF/Lilly Programme on Type 1 Diabetes Research and the Spanish Ministry of Science, Innovation and Universities (PID2019-104475GA-I00) to I.S; and Spanish Ministry of Science, Innovation and Universities (SAF2017-91873-EXP and PGC2018-097573-A-I00) to ACR. M.S.D. and I.G.M. are supported by a Predoctoral Fellowship Grant from the UPV/EHU (Universidad del País Vasco/Euskal Herriko Unibertsitatea) and A.O.G. is supported by a Predoctoral Fellowship Grant from the Education Department of Basque Government.

Institutional Review Board Statement: Not applicable.

Informed Consent Statement: Not applicable.

Data Availability Statement: Not applicable.

Conflicts of Interest: The authors declare no conflict of interest.

\section{References}

1. Bicknell, A.A.; Ricci, E.P. When mRNA translation meets decay. Biochem. Soc. Trans. 2017, 45, 339-351. [CrossRef] [PubMed]

2. Laalami, S.; Zig, L.; Putzer, H. Initiation of mRNA decay in bacteria. Cell. Mol. Life Sci. 2014, 71, 1799-1828. [CrossRef] [PubMed]

3. Hombach, S.; Kretz, M. Non-coding RNAs: Classification, biology and functioning. Adv. Exp. Med. Biol. 2016, 937, 3-17. [PubMed]

4. Yao, R.W.; Wang, Y.; Chen, L.L. Cellular functions of long noncoding RNAs. Nat. Cell Biol. 2019, 21, 542-551. [CrossRef] [PubMed]

5. Ross, J. mRNA Stability in Mammalian Cells. Microbiol. Mol. Biol. Rev. 1995, 59, 423-450. [CrossRef]

6. Pérez-Ortín, J.E.; Alepuz, P.; Chávez, S.; Choder, M. Eukaryotic mRNA decay: Methodologies, pathways, and links to other stages of gene expression. J. Mol. Biol. 2013, 425, 3750-3775. [CrossRef]

7. Radhakrishnan, A.; Green, R. Connections Underlying Translation and mRNA Stability. J. Mol. Biol. 2016, 428, 3558-3564. [CrossRef]

8. Nilsen, T.W. Mechanisms of microRNA-mediated gene regulation in animal cells. Trends Genet. 2007, 23, 243-249. [CrossRef]

9. Eulalio, A.; Huntzinger, E.; Nishihara, T.; Rehwinkel, J.; Fauser, M.; Izaurralde, E. Deadenylation is a widespread effect of miRNA regulation. RNA 2009, 15, 21-32. [CrossRef]

10. Karousis, E.D.; Mühlemann, O. Nonsense-mediated mRNA decay begins where translation ends. Cold Spring Harb. Perspect. Biol. 2019, 11, a032862. [CrossRef]

11. Schoenberg, D.R.; Maquat, L.E. Regulation of cytoplasmic mRNA decay. Nat. Rev. Genet. 2012, 13, 246-259. [CrossRef] [PubMed]

12. Łabno, A.; Tomecki, R.; Dziembowski, A. Cytoplasmic RNA decay pathways-Enzymes and mechanisms. Biochim. Biophys. Acta Mol. Cell Res. 2016, 1863, 3125-3147. [CrossRef] [PubMed]

13. Garneau, N.L.; Wilusz, J.; Wilusz, C.J. The highways and byways of mRNA decay. Nat. Rev. Mol. Cell Biol. 2007, 8, 113-126. [CrossRef] [PubMed]

14. Lykke-Andersen, S.; Jensen, T.H. Nonsense-mediated mRNA decay: An intricate machinery that shapes transcriptomes. Nat. Rev. Mol. Cell Biol. 2015, 16, 665-677. [CrossRef] [PubMed]

15. Moretti, F.; Kaiser, C.; Zdanowicz-Specht, A.; Hentze, M.W. PABP and the poly(A) tail augment microRNA repression by facilitated miRISC binding. Nat. Struct. Mol. Biol. 2012, 19, 603-608. [CrossRef]

16. Iwakawa, H.O.; Tomari, Y. The Functions of MicroRNAs: mRNA Decay and Translational Repression. Trends Cell Biol. 2015, 25, 651-665. [CrossRef]

17. Yoon, J.H.; Abdelmohsen, K.; Gorospe, M. Posttranscriptional gene regulation by long noncoding RNA. J. Mol. Biol. 2013, 425, 3723-3730. [CrossRef]

18. Grudzien-Nogalska, E.; Kiledjian, M. New insights into decapping enzymes and selective mRNA decay. Wiley Interdiscip. Rev. RNA. 2017, 8, e1379. [CrossRef] 
19. Kondo, Y.; Shinjo, K.; Katsushima, K. Long non-coding RNAs as an epigenetic regulator in human cancers. Cancer Sci. 2017, 108, 1927-1933. [CrossRef]

20. Akhade, V.S.; Pal, D.; Kanduri, C. Long Noncoding RNA: Genome organization and mechanism of action. In Advances in Experimental Medicine and Biology; Springer New York LLC: New York, NY, USA, 2017; Volume 1008, pp. 47-74.

21. Esteller, M. Non-coding RNAs in human disease. Nat. Rev. Genet. 2011, 19, 861-874. [CrossRef]

22. Zhang, X.; Wang, W.; Zhu, W.; Dong, J.; Cheng, Y.; Yin, Z.; Shen, F. Mechanisms and Functions of Long Non-Coding RNAs at Multiple Regulatory Levels. Int. J. Mol. Sci. 2019, 20, 5573. [CrossRef] [PubMed]

23. Fang, Y.; Fullwood, M.J. Roles, Functions, and Mechanisms of Long Non-coding RNAs in Cancer. Genom. Proteom. Bioinform. 2016, 14, 42-54. [CrossRef] [PubMed]

24. Chowdhury, I.H.; Narra, H.P.; Sahni, A.; Khanipov, K.; Schroeder, C.L.C.; Patel, J.; Fofanov, Y.; Sahni, S.K. Expression Profiling of Long Noncoding RNA Splice Variants in Human Microvascular Endothelial Cells: Lipopolysaccharide Effects In Vitro. Mediat. Inflamm. 2017, 2017, 3427461. [CrossRef] [PubMed]

25. Fernandes, J.C.R.; Acuña, S.M.; Aoki, J.I.; Floeter-Winter, L.M.; Muxel, S.M. Long non-coding RNAs in the regulation of gene expression: Physiology and disease. Non-Coding RNA 2019, 5, 17. [CrossRef]

26. Braconi, C.; Kogure, T.; Valeri, N.; Huang, N.; Nuovo, G.; Costinean, S.; Negrini, M.; Miotto, E.; Croce, C.M.; Patel, T. MicroRNA29 can regulate expression of the long non-coding RNA gene MEG3 in hepatocellular cancer. Oncogene 2011, 30, 4750-4756. [CrossRef]

27. Fan, M.; Li, X.; Jiang, W.; Huang, Y.; Li, J.; Wang, Z. A long non-coding RNA, PTCSC3, as a tumor suppressor and a target of miRNAs in thyroid cancer cells. Exp. Ther. Med. 2013, 5, 1143-1146. [CrossRef]

28. Liu, C.; Zhang, Y.H.; Deng, Q.; Li, Y.; Huang, T.; Zhou, S.; Cai, Y.D. Cancer-Related Triplets of mRNA-lncRNA-miRNA Revealed by Integrative Network in Uterine Corpus Endometrial Carcinoma. BioMed Res. Int. 2017, 2017, 3859582. [CrossRef]

29. Sun, J.; Wang, X.; Fu, C.; Wang, X.; Zou, J.; Hua, H.; Bi, Z. Long noncoding RNA FGFR3-AS1 promotes osteosarcoma growth through regulating its natural antisense transcript FGFR3. Mol. Biol. Rep. 2016, 43, 427-436. [CrossRef]

30. Valencia-Sanchez, M.A.; Liu, J.; Hannon, G.J.; Parker, R. Control of translation and mRNA degradation by miRNAs and siRNAs. Genes Dev. 2006, 20, 515-524. [CrossRef]

31. Chen, C.Y.; Zheng, D.; Xia, Z.; Shyu, A.B. Ago-TNRC6 triggers microRNA-mediated decay by promoting two deadenylation steps. Nat. Struct. Mol. Biol. 2009, 16, 1160-1166. [CrossRef]

32. Salmena, L.; Poliseno, L.; Tay, Y.; Kats, L.; Pandolfi, P.P. A ceRNA hypothesis: The rosetta stone of a hidden RNA language? Cell 2011, 146, 353-358. [CrossRef] [PubMed]

33. Mahmoudi, S.; Henriksson, S.; Corcoran, M.; Méndez-Vidal, C.; Wiman, K.G.; Farnebo, M. Wrap53, a Natural p53 Antisense Transcript Required for p53 Induction upon DNA Damage. Mol. Cell 2009, 33, 462-471. [CrossRef] [PubMed]

34. Su, W.Y.; Li, J.T.; Cui, Y.; Hong, J.; Du, W.; Wang, Y.C.; Lin, Y.W.; Xiong, H.; Wang, J.L.; Kong, X.; et al. Bidirectional regulation between WDR83 and its natural antisense transcript DHPS in gastric cancer. Cell Res. 2012, 22, 1374-1389. [CrossRef] [PubMed]

35. Katayama, S.; Tomaru, Y.; Kasukawa, T.; Waki, K.; Nakanishi, M.; Nakamura, M.; Nishida, H.; Yap, C.C.; Suzuki, M.; Kawai, J.; et al. Molecular biology: Antisense transcription in the mammalian transcriptome. Science 2005, 309, 1564-1566. [PubMed]

36. Nishizawa, M.; Ikeya, Y.; Okumura, T.; Kimura, T. Post-transcriptional inducible gene regulation by natural antisense RNA. Front. Biosci. 2015, 20, 1-36. [CrossRef] [PubMed]

37. Wanowska, E.; Kubiak, M.R.; Rosikiewicz, W.; Makałowska, I.; Szcześniak, M.W. Natural antisense transcripts in diseases: From modes of action to targeted therapies. Wiley Interdiscip. Rev. RNA 2018, 9, e1461. [CrossRef]

38. Pelechano, V.; Steinmetz, L.M. Gene regulation by antisense transcription. Nat. Rev. Genet. 2013, 14, 880-893. [CrossRef]

39. Zinad, H.S.; Natasya, I.; Werner, A. Natural antisense transcripts at the interface between host genome and mobile genetic elements. Front. Microbiol. 2017, 8, 2292. [CrossRef]

40. Faghihi, M.A.; Wahlestedt, C. Regulatory roles of natural antisense transcripts. Nat. Rev. Mol. Cell Biol. 2009, 10, 637-643. [CrossRef]

41. Roberson, E.D.; Mucke, L. 100 Years and counting: Prospects for defeating Alzheimer's disease. Science 2006, 314, 781-784. [CrossRef]

42. Faghihi, M.A.; Zhang, M.; Huang, J.; Modarresi, F.; van der Brug, M.P.; Nalls, M.A.; Cookson, M.R.; St-Laurent, G.; Wahlestedt, C. Evidence for natural antisense transcript-mediated inhibition of microRNA function. Genome Biol. 2010, 11, R56. [CrossRef] [PubMed]

43. Zhu, L.; Wei, Q.; Qi, Y.; Ruan, X.; Wu, F.; Li, L.; Zhou, J.; Liu, W.; Jiang, T.; Zhang, J.; et al. PTB-AS, a Novel Natural Antisense Transcript, Promotes Glioma Progression by Improving PTBP1 mRNA Stability with SND1. Mol. Ther. 2019, 27, $1621-1637$. [CrossRef] [PubMed]

44. Izaguirre, D.I.; Zhu, W.; Hai, T.; Cheung, H.C.; Krahe, R.; Cote, G.J. PTBP1-dependent regulation of USP5 alternative RNA splicing plays a role in glioblastoma tumorigenesis. Mol. Carcinog. 2012, 51, 895-906. [CrossRef]

45. Xue, Y.; Ouyang, K.; Huang, J.; Zhou, Y.; Ouyang, H.; Li, H.; Wang, G.; Wu, Q.; Wei, C.; Bi, Y.; et al. Direct conversion of fibroblasts to neurons by reprogramming PTB-regulated MicroRNA circuits. Cell 2013, 152, 82-96. [CrossRef] [PubMed]

46. Bi, Y.; Jing, Y.; Cao, Y. Overexpression of miR-100 inhibits growth of osteosarcoma through FGFR3. Tumor Biol. 2015, 36, 8405-8411. [CrossRef] 
47. Yuan, J.H.; Liu, X.N.; Wang, T.T.; Pan, W.; Tao, Q.F.; Zhou, W.P.; Wang, F.; Sun, S.H. The MBNL3 splicing factor promotes hepatocellular carcinoma by increasing PXN expression through the alternative splicing of lncRNA-PXN-AS1. Nat. Cell Biol. 2017, 19, 820-832. [CrossRef]

48. Wang, G.Q.; Wang, Y.; Xiong, Y.; Chen, X.C.; Ma, M.L.; Cai, R.; Gao, Y.; Sun, Y.M.; Yang, G.S.; Pang, W.J. Sirt1 AS lncRNA interacts with its mRNA to inhibit muscle formation by attenuating function of miR-34a. Sci. Rep. 2016, 6, 21865. [CrossRef]

49. Pardo, P.S.; Boriek, A.M. The physiological roles of Sirt1 in skeletal muscle. Aging 2011, 3, 430-437. [CrossRef]

50. Barbagallo, C.; Brex, D.; Caponnetto, A.; Cirnigliaro, M.; Scalia, M.; Magnano, A.; Caltabiano, R.; Barbagallo, D.; Biondi, A.; Cappellani, A.; et al. LncRNA UCA1, Upregulated in CRC Biopsies and Downregulated in Serum Exosomes, Controls mRNA Expression by RNA-RNA Interactions. Mol. Ther. Nucleic Acids 2018, 12, 229-241. [CrossRef]

51. Ulitsky, I.; Shkumatava, A.; Jan, C.H.; Sive, H.; Bartel, D.P. Conserved function of lincRNAs in vertebrate embryonic development despite rapid sequence evolution. Cell 2011, 147, 1537-1550. [CrossRef]

52. Yang, J.; Jiang, B.; Hai, J.; Duan, S.; Dong, X.; Chen, C. Long noncoding RNA opa-interacting protein 5 antisense transcript 1 promotes proliferation and invasion through elevating integrin $\alpha 6$ expression by sponging miR-143-3p in cervical cancer. J. Cell. Biochem. 2019, 120, 907-916. [CrossRef] [PubMed]

53. Chen, X.; Xiong, D.; Yang, H.; Ye, L.; Mei, S.; Wu, J.; Chen, S.; Shang, X.; Wang, K.; Huang, L. Long noncoding RNA OPAinteracting protein 5 antisense transcript 1 upregulated SMAD3 expression to contribute to metastasis of cervical cancer by sponging miR-143-3p. J. Cell. Physiol. 2019, 234, 5264-5275. [CrossRef] [PubMed]

54. Radhakrishnan, H.; Walther, W.; Zincke, F.; Kobelt, D.; Imbastari, F.; Erdem, M.; Kortüm, B.; Dahlmann, M.; Stein, U. MACC1—the first decade of a key metastasis molecule from gene discovery to clinical translation. Cancer Metastasis Rev. 2018, 37, 805-820. [CrossRef]

55. Zhao, Y.; Liu, Y.; Lin, L.; Huang, Q.; He, W.; Zhang, S.; Dong, S.; Wen, Z.; Rao, J.; Liao, W.; et al. The lncRNA MACC1-AS1 promotes gastric cancer cell metabolic plasticity via AMPK/Lin28 mediated mRNA stability of MACC1. Mol. Cancer 2018, 17, 69. [CrossRef] [PubMed]

56. Zhang, X.; Zhou, Y.; Chen, S.; Li, W.; Chen, W.; Gu, W. LncRNA MACC1-AS1 sponges multiple miRNAs and RNA-binding protein PTBP1. Oncogenesis 2019, 8, 73. [CrossRef]

57. Johnsson, P.; Ackley, A.; Vidarsdottir, L.; Lui, W.O.; Corcoran, M.; Grandér, D.; Morris, K.V. A pseudogene long-noncoding-RNA network regulates PTEN transcription and translation in human cells. Nat. Struct. Mol. Biol. 2013, 20, 440-446. [CrossRef]

58. Bejerano, G.; Pheasant, M.; Makunin, I.; Stephen, S.; Kent, W.J.; Mattick, J.S.; Haussler, D. Ultraconserved elements in the human genome. Science 2004, 304, 1321-1325. [CrossRef]

59. Xiao, L.; Wu, J.; Wang, J.Y.; Chung, H.K.; Kalakonda, S.; Rao, J.N.; Gorospe, M.; Wang, J.Y. Long Noncoding RNA uc.173 Promotes Renewal of the Intestinal Mucosa by Inducing Degradation of MicroRNA 195. Gastroenterology 2018, 154, 599-611. [CrossRef]

60. Franklin, J.L.; Rankin, C.R.; Levy, S.; Snoddy, J.R.; Zhang, B.; Washington, M.K.; Thomson, J.M.; Whitehead, R.H.; Coffey, R.J. Malignant transformation of colonic epithelial cells by a colon-derived long noncoding RNA. Biochem. Biophys. Res. Commun. 2013, 440, 99-104. [CrossRef]

61. Chen, C.Y.; Shyu, A.B. AU-rich elements: Characterization and importance in mRNA degradation. Trends Biochem Sci. 1995, 20, 465-470. [CrossRef]

62. Vlasova, I.A.; Bohjanen, P.R. Posttranscriptional regulation of gene networks by GU-rich elements and CELF proteins. RNA Biol. 2008, 5, 201-207. [CrossRef] [PubMed]

63. Wu, X.; Brewer, G. The regulation of mRNA stability in mammalian cells: 2.0. Gene 2012, 500, 10-21. [CrossRef] [PubMed]

64. Corley, M.; Burns, M.C.; Yeo, G.W. How RNA-Binding Proteins Interact with RNA: Molecules and Mechanisms. Mol. Cell 2020, 78, 9-29. [CrossRef]

65. Licatalosi, D.D.; Darnell, R.B. Resolving RNA complexity to decipher regulatory rules governing biological networks. Nat. Rev. Genet. 2010, 11, 75-87. [CrossRef] [PubMed]

66. Ferrè, F.; Colantoni, A.; Helmer-Citterich, M. Revealing protein-lncRNA interaction. Brief. Bioinform. 2016, 17, 106-116. [CrossRef]

67. Zhu, J.J.; Fu, H.J.; Wu, Y.G.; Zheng, X.F. Function of lncRNAs and approaches to lncRNA-protein interactions. Sci. China Life Sci. 2013, 56, 876-885. [CrossRef]

68. Wang, X.; Arai, S.; Song, X.; Reichart, D.; Du, K.; Pascual, G.; Tempst, P.; Rosenfeld, M.G.; Glass, C.K.; Kurokawa, R. Induced ncRNAs allosterically modify RNA-binding proteins in cis to inhibit transcription. Nature 2008, 454, 126-130. [CrossRef]

69. McHugh, C.A.; Chen, C.K.; Chow, A.; Surka, C.F.; Tran, C.; McDonel, P.; Pandya-Jones, A.; Blanco, M.; Burghard, C.; Moradian, A.; et al. The Xist lncRNA interacts directly with SHARP to silence transcription through HDAC3. Nature 2015, 521, 232-236. [CrossRef]

70. Noh, J.H.; Kim, K.M.; McClusky, W.G.; Abdelmohsen, K.; Gorospe, M. Cytoplasmic functions of long noncoding RNAs. Wiley Interdiscip. Rev. RNA 2018, 9, e1471. [CrossRef]

71. He, R.Z.; Luo, D.X.; Mo, Y.Y. Emerging roles of lncRNAs in the post-transcriptional regulation in cancer. Genes Dis. 2019, 6, 6-15. [CrossRef]

72. Briata, P.; Gherzi, R. Long Non-Coding RNA-Ribonucleoprotein Networks in the Post-Transcriptional Control of Gene Expression. Non-Coding RNA 2020, 6, 40. [CrossRef] [PubMed]

73. Cao, L.; Zhang, P.; Li, J.; Wu, M. Last, a c-Myc-inducible long noncoding RNA, cooperates with CNBP to promote CCND1 MRNA stability in human cells. eLife 2017, 6, 1-28. [CrossRef] [PubMed] 
74. Xu, H.; Jiang, Y.; Xu, X.; Su, X.; Liu, Y.; Ma, Y.; Zhao, Y.; Shen, Z.; Huang, B.; Cao, X. Inducible degradation of lncRNA Sros1 promotes IFN- $\gamma$-mediated activation of innate immune responses by stabilizing Stat1 mRNA. Nat. Immunol. 2019, 20, 1621-1630. [CrossRef] [PubMed]

75. Abdelmohsen, K.; Panda, A.C.; Kang, M.J.; Guo, R.; Kim, J.; Grammatikakis, I.; Yoon, J.H.; Dudekula, D.B.; Noh, J.H.; Yang, X.; et al. NAR Breakthrough Article 7SL RNA represses p53 translation by competing with HuR. Nucleic Acids Res. 2014, 42, 10099-10111. [CrossRef]

76. Cmarik, J.L.; Min, H.; Hegamyer, G.; Zhan, S.; Kulesz-Martin, M.; Yoshinaga, H.; Matsuhashi, S.; Colburn, N.H. Differentially expressed protein Pdcd4 inhibits tumor promoter-induced neoplastic transformation. Proc. Natl. Acad. Sci. USA 1999, 96, 14037-14042. [CrossRef]

77. Jadaliha, M.; Gholamalamdari, O.; Tang, W.; Zhang, Y.; Petracovici, A.; Hao, Q.; Tariq, A.; Kim, T.G.; Holton, S.E.; Singh, D.K.; et al. A natural antisense lncRNA controls breast cancer progression by promoting tumor suppressor gene mRNA stability. PLoS Genet. 2018, 14, e1007802. [CrossRef]

78. Cammas, A.; Sanchez, B.J.; Lian, X.J.; Dormoy-Raclet, V.; van derGiessen, K.; de Silanes, I.L.; Ma, J.; Wilusz, C.; Richardson, J.; Gorospe, M.; et al. Destabilization of nucleophosmin mRNA by the HuR/KSRP complex is required for muscle fibre formation. Nat. Commun. 2014, 5, 4190. [CrossRef]

79. Zou, Z.; Ma, T.; He, X.; Zhou, J.; Ma, H.; Xie, M.; Liu, Y.; Lu, D.; Di, S.; Zhang, Z. Long intergenic non-coding RNA 00324 promotes gastric cancer cell proliferation via binding with HuR and stabilizing FAM83B expression article. Cell Death Dis. 2018, 9, 717. [CrossRef]

80. Pan, L.; Li, Y.; Jin, L.; Li, J.; Xu, A. TRPM2-AS promotes cancer cell proliferation through control of TAF15. Int. J. Biochem. Cell Biol. 2020, 120, 105683. [CrossRef]

81. Kawasaki, Y.; Komiya, M.; Matsumura, K.; Negishi, L.; Suda, S.; Okuno, M.; Yokota, N.; Osada, T.; Nagashima, T.; Hiyoshi, M.; et al. MYU, a Target lncRNA for Wnt/c-Myc Signaling, Mediates Induction of CDK6 to Promote Cell Cycle Progression. Cell Rep. 2016, 16, 2554-2564. [CrossRef]

82. Zhang, L.; Yang, Z.; Trottier, J.; Barbier, O.; Wang, L. Long noncoding RNA MEG3 induces cholestatic liver injury by interaction with PTBP1 to facilitate shp mRNA decay. Hepatology 2017, 65, 604-615. [CrossRef] [PubMed]

83. Liu, X.; Li, D.; Zhang, W.; Guo, M.; Zhan, Q. Long non-coding RNA gadd7 interacts with TDP-43 and regulates Cdk6 mRNA decay. EMBO J. 2012, 31, 4415-4427. [CrossRef] [PubMed]

84. Lu, Y.; Liu, X.; Xie, M.; Liu, M.; Ye, M.; Li, M.; Chen, X.-M.; Li, X.; Zhou, R. The NF-kB-Responsive Long Noncoding RNA FIRRE Regulates Posttranscriptional Regulation of Inflammatory Gene Expression through Interacting with hnRNPU. J. Immunol. 2017, 199, 3571-3582. [CrossRef]

85. Giovarelli, M.; Bucci, G.; Ramos, A.; Bordo, D.; Wilusz, C.J.; Chen, C.Y.; Puppo, M.; Briata, P.; Gherzi, R. H19 long noncoding RNA controls the mRNA decay promoting function of KSRP. Proc. Natl. Acad. Sci. USA 2014, 111, E5023-E5028. [CrossRef] [PubMed]

86. Lee, S.; Kopp, F.; Chang, T.C.; Sataluri, A.; Chen, B.; Sivakumar, S.; Yu, H.; Xie, Y.; Mendell, J.T. Noncoding RNA NORAD Regulates Genomic Stability by Sequestering PUMILIO Proteins. Cell 2016, 164, 69-80. [CrossRef]

87. Lan, Y.; Xiao, X.; He, Z.; Luo, Y.; Wu, C.; Li, L.; Song, X. Long noncoding RNA OCC-1 suppresses cell growth through destabilizing HuR protein in colorectal cancer. Nucleic Acids Res. 2018, 46, 5809-5821. [CrossRef]

88. Kim, J.; Abdelmohsen, K.; Yang, X.; De, S.; Grammatikakis, I.; Noh, J.H.; Gorospe, M. LncRNA OIP5-AS1/cyrano sponges RNA-binding protein HuR. Nucleic Acids Res. 2016, 44, 2378-2392. [CrossRef]

89. Gumireddy, K.; Li, A.; Yan, J.; Setoyama, T.; Johannes, G.J.; Ørom, U.A.; Tchou, J.; Liu, Q.; Zhang, L.; Speicher, D.W.; et al. Identification of a long non-coding RNA-associated RNP complex regulating metastasis at the translational step. EMBO J. 2013, 32, 2672-2684. [CrossRef]

90. Yoon, J.H.; Abdelmohsen, K.; Srikantan, S.; Yang, X.; Martindale, J.L.; De, S.; Huarte, M.; Zhan, M.; Becker, K.G.; Gorospe, M. LincRNA-p21 Suppresses Target mRNA Translation. Mol. Cell 2012, 47, 648-655. [CrossRef]

91. Kang, M.J.; Abdelmohsen, K.; Hutchison, E.R.; Mitchell, S.J.; Grammatikakis, I.; Guo, R.; Noh, J.H.; Martindale, J.L.; Yang, X.; Lee, E.K.; et al. HuD regulates coding and noncoding RNA to induce APP $\rightarrow$ A $\beta$ processing. Cell Rep. 2014, 7, 1401-1409. [CrossRef]

92. Kim, Y.K.; Furic, L.; Parisien, M.; Major, F.; DesGroseillers, L.; Maquat, L.E. Staufen1 regulates diverse classes of mammalian transcripts. EMBO J. 2007, 26, 2670-2681. [CrossRef]

93. Gong, C.; Maquat, L.E. LncRNAs transactivate STAU1-mediated mRNA decay by duplexing with 39 UTRs via Alu eleme. Nature 2011, 470, 284-290. [CrossRef]

94. Kretz, M.; Siprashvili, Z.; Chu, C.; Webster, D.E.; Zehnder, A.; Qu, K.; Lee, C.S.; Flockhart, R.J.; Groff, A.F.; Chow, J.; et al. Control of somatic tissue differentiation by the long non-coding RNA TINCR. Nature 2013, 493, 231-235. [CrossRef] [PubMed]

95. Xu, T.P.; Liu, X.X.; Xia, R.; Yin, L.; Kong, R.; Chen, W.M.; Huang, M.D.; Shu, Y.Q. SP1-induced upregulation of the long noncoding RNA TINCR regulates cell proliferation and apoptosis by affecting KLF2 mRNA stability in gastric cancer. Oncogene 2015, 34, 5648-5661. [CrossRef] [PubMed]

96. Uchida, T.; Rossignol, F.; Matthay, M.A.; Mounier, R.; Couette, S.; Clottes, E.; Clerici, C. Prolonged hypoxia differentially regulates hypoxia-inducible factor (HIF)- $1 \alpha$ and HIF- $2 \alpha$ expression in lung epithelial cells: Implication of natural antisense HIF-1 $\alpha$. J. Biol. Chem. 2004, 279, 14871-14878. [CrossRef] [PubMed]

97. Rossignol, F.; Vaché, C.; Clottes, E. Natural antisense transcripts of hypoxia-inducible factor 1alpha are detected in different normal and tumour human tissues. Gene 2002, 299, 135-140. [CrossRef] 
98. Bhartiya, D.; Scaria, V. Genomic variations in non-coding RNAs: Structure, function and regulation. Genomics 2016, 107, 59-68. [CrossRef] [PubMed]

99. Lu, X.; Ding, Y.; Bai, Y.; Li, J.; Zhang, G.; Wang, S.; Gao, W.; Xu, L.; Wang, H. Detection of Allosteric Effects of lncRNA Secondary Structures Altered by SNPs in Human Diseases. Front. Cell Dev. Biol. 2020, 8, 1-11. [CrossRef] [PubMed]

100. Castellanos-Rubio, A.; Ghosh, S. Disease-associated SNPs in inflammation-related lncRNAs. Front. Immunol. 2019, 10, 1-9. [CrossRef]

101. Ricaño-Ponce, I.; Zhernakova, D.v.; Deelen, P.; Luo, O.; Li, X.; Isaacs, A.; Karjalainen, J.; di Tommaso, J.; Borek, Z.A.; Zorro, M.M.; et al. Refined mapping of autoimmune disease associated genetic variants with gene expression suggests an important role for non-coding RNAs. J. Autoimmun. 2016, 68, 62-74. [CrossRef]

102. Gonzalez-Moro, I.; Olazagoitia-Garmendia, A.; Colli, M.L.; Cobo-Vuilleumier, N.; Postler, T.S.; Marselli, L.; Marchetti, P.; Ghosh, S.; Gauthier, B.R.; Eizirik, D.L.; et al. The T1D-associated lncRNA Lnc13 modulates human pancreatic $\beta$ cell inflammation by allele-specific stabilization of STAT1 mRNA. Proc. Natl. Acad. Sci. USA 2020, 117, 8661-8663. [CrossRef] [PubMed]

103. Castellanos-Rubio, A.; Fernandez-Jimenez, N.; Kratchmarov, R.; Luo, X.; Bhagat, G.; Green, P.H.R.; Schneider, R.; Kiledjian, M.; Bilbao, J.R.; Ghosh, S. A long noncoding RNA associated with susceptibility to celiac disease. Science 2016, 352, 91-95. [CrossRef]

104. De Beeck, A.O.; Eizirik, D.L. Viral infections in type 1 diabetes mellitus-why the $\beta$ cells? Nat. Rev. Endocrinol. 2016, 12, 263-273 [CrossRef] [PubMed]

105. Huang, J.; Zhang, A.; Ho, T.T.; Zhang, Z.; Zhou, N.; Ding, X.; Zhang, X.; Xu, M.; Mo, Y.Y. Linc-RoR promotes c-Myc expression through hnRNPi and AUF1. Nucleic Acids Res. 2015, 44, 3059-3069. [CrossRef] [PubMed]

106. Rossi, M.; Bucci, G.; Rizzotto, D.; Bordo, D.; Marzi, M.J.; Puppo, M.; Flinois, A.; Spadaro, D.; Citi, S.; Emionite, L.; et al. LncRNA EPR controls epithelial proliferation by coordinating Cdkn1a transcription and mRNA decay response to TGF- $\beta$. Nat. Commun. 2019, 10, 1969. [CrossRef]

107. Zapparoli, E.; Briata, P.; Rossi, M.; Brondolo, L.; Bucci, G.; Gherzi, R. Comprehensive multi-omics analysis uncovers a group of TGF- $\beta$-regulated genes among lncRNA EPR direct transcriptional targets. Nucleic Acids Res. 2020, 48, 9053-9066. [CrossRef]

108. Boo, S.H.; Kim, Y.K. The emerging role of RNA modifications in the regulation of mRNA stability. Exp. Mol. Med. 2020, 52, 400-408. [CrossRef]

109. Wang, X.; Lu, Z.; Gomez, A.; Hon, G.C.; Yue, Y.; Han, D.; Fu, Y.; Parisien, M.; Dai, Q.; Jia, G.; et al. N 6-methyladenosine-dependent regulation of messenger RNA stability. Nature 2014, 505, 117-120. [CrossRef]

110. Huang, H.; Weng, H.; Sun, W.; Qin, X.; Shi, H.; Wu, H.; Zhao, B.S.; Mesquita, A.; Liu, C.; Yuan, C.L.; et al. Recognition of RNA N 6-methyladenosine by IGF2BP Proteins Enhances mRNA Stability and Translation contributed reagents/analytic tools and/or grant support; HHS Public Access. Nat. Cell Biol. 2018, 20, 285-295. [CrossRef]

111. Wang, X.; Zhao, B.S.; Roundtree, I.A.; Lu, Z.; Han, D.; Ma, H.; Weng, X.; Chen, K.; Shi, H.; He, C. N6-methyladenosine modulates messenger RNA translation efficiency. Cell 2015, 161, 1388-1399. [CrossRef]

112. Wang, X.; Zhang, J.; Wang, Y. Long noncoding RNA GAS5-AS1 suppresses growth and metastasis of cervical cancer by increasing GAS5 stability. Am. J. Transl. Res. 2019, 11, 4909-4921. [PubMed]

113. Yan, J.; Huang, X.; Zhang, X.; Chen, Z.; Ye, C.; Xiang, W.; Huang, Z. LncRNA LINC00470 promotes the degradation of PTEN mRNA to facilitate malignant behavior in gastric cancer cells. Biochem. Biophys. Res. Commun. 2019, 521, 887-893. [CrossRef] [PubMed]

114. Wang, C.; Gu, Y.; Zhang, E.; Zhang, K.; Qin, N.; Dai, J.; Zhu, M.; Liu, J.; Xie, K.; Jiang, Y.; et al. A cancer-testis non-coding RNA LIN28B-AS1 activates driver gene LIN28B by interacting with IGF2BP1 in lung adenocarcinoma. Oncogene 2019, 38, 1611-1624. [CrossRef] [PubMed]

115. Sun, T.; Wu, Z.; Wang, X.; Wang, Y.; Hu, X.; Qin, W.; Lu, S.; Xu, D.; Wu, Y.; Chen, Q.; et al. LNC942 promoting METTL14-mediated m6A methylation in breast cancer cell proliferation and progression. Oncogene 2020, 39, 5358-5372. [CrossRef] 